\title{
Signaling by proinflammatory cytokines: oligomerization of TRAF2 and TRAF6 is sufficient for JNK and IKK activation and target gene induction via an amino-terminal effector domain
}

\author{
Véronique Baud, ${ }^{1,3}$ Zheng-Gang Liu, ${ }^{1,3}$ Brydon Bennett, ${ }^{2}$ Nobutaka Suzuki, ${ }^{1}$ Ying Xia, ${ }^{1}$ \\ and Michael Karin ${ }^{1,4}$ \\ ${ }^{1}$ Laboratory of Gene Regulation and Signal Transduction, Department of Pharmacology, University of California, San Diego, \\ School of Medicine, La Jolla, California 92093-0636 USA; ${ }^{2}$ Signal Pharmaceuticals, San Diego, California 92121 USA
}

Interleukin-1 (IL-1) and tumor necrosis factor (TNF- $\alpha$ ) stimulate transcription factors AP-1 and NF- $\mathrm{B}$ through activation of the MAP kinases JNK and p38 and the IKB kinase (IKK), respectively. The TNF- $\alpha$ and IL-1 signals are transduced through TRAF2 and TRAF6, respectively. Overexpressed TRAF2 or TRAF6 activate JNK, p38, or IKK in the absence of extracellular stimulation. By replacing the carboxy-terminal TRAF domain of TRAF2 and TRAF6 with repeats of the immunophilin FKBP12, we demonstrate that their effector domains are composed of their amino-terminal Zn and RING fingers. Oligomerization of the TRAF2 effector domain results in specific binding to MEKK1, a protein kinase capable of JNK, p38, and IKK activation, and induction of TNF- $\alpha$ and IL-1 responsive genes. TNF- $\alpha$ also enhances the binding of native TRAF2 to MEKK1 and stimulates the kinase activity of the latter. Thus, TNF- $\alpha$ and IL-1 signaling is based on oligomerization of TRAF2 and TRAF6 leading to activation of effector kinases.

[Key Words: Signaling; cytokines; protein kinase; effector domain]

Received November 24, 1998; revised version accepted April 1, 1999.

Interleukin-1 (IL-1) and tumor necrosis factor (TNF- $\alpha$ ) are proinflammatory cytokines that are key to generation of systemic and local responses to infection, injury, and immunological challenges (Tracey and Cerami 1993; Dinarello 1994). Produced mainly by activated macrophages and monocytes, IL- 1 and TNF- $\alpha$ participate in lymphocyte and leukocyte activation and trafficking, fever, acute-phase response, and cartilage remodeling (Tracey and Cerami 1993; Dinarello 1994). The biological functions of IL- 1 and TNF- $\alpha$ are very similar, which is quite remarkable given the fact that the two cytokines, as well as their receptors, belong to different structural classes. The effects of IL-1 are mediated by the type-1 IL-1 receptor (IL-1R1) and IL-1R accessory protein (IL-1RAcP) (Dinarello 1994; Greenfeder et al. 1995). TNF- $\alpha$ exerts its effects through type 1 (TNFR1) or type 2 (TNFR2) receptors (Tartaglia and Goeddel 1992). Despite total absence of chemical and structural similarities, occupancy of these receptors leads to activation of two transcription factors, NF- $\mathrm{B}$ and AP-1, that induce genes involved in acute and chronic inflammatory re-

\footnotetext{
${ }^{3}$ These authors contributed equally to this work.

${ }^{4}$ Corresponding author.

E-MAIL karinoffice@ucsd.edu; FAX (619) 534-8158.
}

sponses (Baeuerle and Henkel 1994; Karin 1995; Barnes and Karin 1997). NF-кB is regulated primarily by phosphorylation of inhibitory proteins, the IкBs, which retain it in the cytoplasm of nonstimulated cells (Beg and Baldwin 1993; Verma et al. 1995). Following cell stimulation the IкBs are phosphorylated by a cytokine-activated protein kinase complex called IкB kinase (IKK) (DiDonato et al. 1997; Mercurio et al. 1997; Régnier et al. 1997; Woronicz et al. 1997; Zandi et al. 1997, 1998; Rothwarf et al. 1998; Yamaoka et al. 1998). This results in the ubiquitination and degradation of the IкBs and the nuclear translocation of freed NF-кB. Once in the nucleus, NF- $\kappa \mathrm{B}$ activates transcription of genes whose promoters contain $\kappa \mathrm{B}$ sites. Many of these genes also contain binding sites for AP-1 whose activity is regulated by members of the mitogen-activated protein kinase (MAPK) family, which enter the nucleus upon stimulation to phosphorylate DNA-bound transcription factors (Karin 1995). Most relevant to TNF- $\alpha$ and IL-1 signaling are the so-called stress-activated protein kinases (SAPKs), c-Jun amino (N)-terminal kinases (JNKs), and p38 (Dérijard et al. 1994; Han et al. 1994; Kallunki et al. 1994; Kyriakis et al. 1994; Lee et al. 1994; Rouse et al. 1994). Both the JNKs and the p38s are activated rapidly and potently in response to TNF- $\alpha$ or IL-1, through 
MAPK cascades (Dérijard et al. 1995; Lin et al. 1995). In some cells TNF- $\alpha$ or IL- 1 also stimulates ERK activity, which may also contribute to stimulation of AP-1 activity (Westwick et al. 1994).

Unlike growth factor receptors, which contain intrinsic tyrosine kinase domains (Schlessinger and Ullrich 1992), or most other cytokine receptors, which are coupled to Janus kinase (JAK) tyrosine kinases (Ihle 1996), the TNF- $\alpha$ and IL-1 receptors do not appear to function through tyrosine kinases. Instead they operate by recruiting a variety of signal transducers. Binding of TNF- $\alpha$ to TNFR1 or TNFR2 induces receptor trimerization and recruitment of several downstream signaling proteins to their cytoplasmic domains (Hsu et al. 1995, 1996). TNFR1 interacts with the signaling protein TNFR1-associated death domain protein (TRADD), which serves as a platform to recruit at least three additional mediators: TRAF2 (Hsu et al. 1995, 1996), receptor interacting protein (RIP) (Stanger et al. 1995), and Fasassociated protein with death domain (FADD) (Chinnaiyan et al. 1995). TNFR2 activation results in direct recruitment of TRAF2 and its relative TRAF1 (Rothe et al. 1994). Transfection experiments implicated TRAF2 as a critical mediator of NF- $\mathrm{kB}$ (Rothe et al. 1995), JNK, and p38 activation (Liu et al. 1996; Natoli et al. 1997; Reinhard et al. 1997). However, traf2 ${ }^{-/-}$cells derived from TRAF2-deficient mice or cells from mice expressing a dominant-negative form of TRAF2 are severely defective in TNF- $\alpha$-induced JNK activation, whereas they still exhibit considerable, albeit slower, NF-кB activation (S.Y. Lee et al. 1997; Yeh et al. 1997). The basis for the differential dependence of the AP-1 (JNK and p38) and NF-кB pathways on TRAF2 is not understood, but it was suggested that TRAF5, may substitute for TRAF2 in NF-кB activation (S.Y. Lee et al. 1997; Yeh et al. 1997).

Binding of IL-1 to IL-1R1 induces heterodimerization with IL-1RAcP (Greenfeder et al. 1995) and recruitment of the adapter protein MyD88, which mediates the interaction of the IL-1 receptor-associated kinase (IRAK) with the cytoplasmic domain of the receptor (Cao et al. 1996a; Wesche et al. 1997). In turn, IRAK recruits TRAF6 to the activated receptor (Cao et al. 1996b). Thus, despite the lack of structural and chemical similarities between the TNF- $\alpha$ and IL- 1 receptors, they both use TRAF proteins as signal transducers.

Like most TRAF proteins, TRAF2 and TRAF6 are composed of a highly conserved carboxy-terminal TRAF domain and a more variable amino-terminal domain, which contains a RING finger and several Zn fingers (Rothe et al. 1994; Cao et al. 1996b; Arch et al. 1998). Overexpression of either TRAF2 or TRAF6 is sufficient to activate signaling pathways leading to NF-кB and AP-1 in the absence of extracellular stimuli (Rothe et al. 1995; Cao et al. 1996b; Liu et al. 1996; Song et al. 1997). It was found previously that the carboxy-terminal TRAF domains can mediate homotypic and heterotypic TRAFTRAF interactions, as well as receptor docking (Rothe et al. 1994; Cheng et al. 1995; Cao et al. 1996b). Although these results suggest the carboxy-terminal TRAF domains function mainly as receptor docking and oligo- merization domains, other experiments implicated them in binding of putative effectors, such as the NF-кB-inducing kinase NIK (Malinin et al. 1997). Such results, therefore, suggest that the carboxy-terminal TRAF domain may function as an effector domain. On the other hand, the more variable region of TRAF proteins is their amino-terminal half (Cao et al. 1996b), and these regions in TRAF2 and TRAF6 specify their ability to activate NF-кB (Rothe et al. 1995; Cao et al. 1996b; Takeuchi et al. 1996; Song et al. 1997). However, the amino-terminal halves do not dictate binding of putative effectors such as NIK, which interacts with all TRAFs regardless of their ability to activate NF-кB (Song et al. 1997). Nevertheless, we postulated that the "signaling end" of TRAF2 and TRAF6 is their amino-terminal domain, whereas the carboxy-terminal TRAF domain may function only as an oligomerization and receptor docking domain. To test this hypothesis, we fused the amino-terminal halves of TRAF2 or TRAF6 to a threefold repeat of the FK506 binding immunophilin FKBP12 (Schreiber 1991) and used the dimeric ligand FK1012 to induce oligomerization of the TRAF-FKBP12 chimeras (Spencer et al. 1993). We provide evidence that the critical event in TRAF-mediated TNF- $\alpha$ and IL-1 signaling is ligand-induced TRAF oligomerization and that once oligomerized the amino-terminal domains of TRAF2 and TRAF6 gain the ability to stably interact with effectors, one of which may be the MAPK kinase (MAPKK) kinase (MAPKKK) MEKK1. Oligomerization of a stably expressed TRAF2-FKBP12 chimera induces the same spectrum of genes, coding for inflammatory mediators, as normally induced by TNF- $\alpha$ or IL-1 themselves.

\section{Results}

\section{IRAK and TRAF6 mediate JNK and p38 activation}

IRAK and TRAF6 are critical intermediates in the pathway leading from IL-1R1 to NF-kB (Cao et al. 1996a,b). To examine their involvement in JNK and p38 activation, IRAK or TRAF6 expression vectors were cotransfected into HeLa or HEK 293 cells with expression vectors encoding hemagglutinin (HA)-tagged JNK1 or p38 $\alpha$. Both IRAK and TRAF6 activated JNK efficiently (Fig. 1A) and p38 (Fig. 1B). IRAK( $\Delta 218-507)$, a truncation mutant lacking the protein kinase domain, or TRAF6(289-522), lacking the amino-terminal RING and $\mathrm{Zn}$ fingers, did not activate either JNK1 or p38 (Fig. 1C; data not shown). On the contrary, both mutants completely inhibited JNK completely (Fig. 1A) or p38 (Fig. 1B) activation by IL-1. Thus, IRAK and TRAF6 are critical intermediates in the pathway leading from IL-1R1 to JNK or p38.

We addressed the relationship between IRAK and TRAF6 by examining the ability of the truncation mutants described above to interfere with the action of the native proteins. TRAF6(289-522) blocked JNK1 activation by IRAK, but IRAK $(\Delta 218-507)$ did not interfere with JNK activation by TRAF6 (Fig. 1C). These results are consistent with those of protein recruitment experiments (Cao et al. 1996b) and indicate that TRAF6 acts 


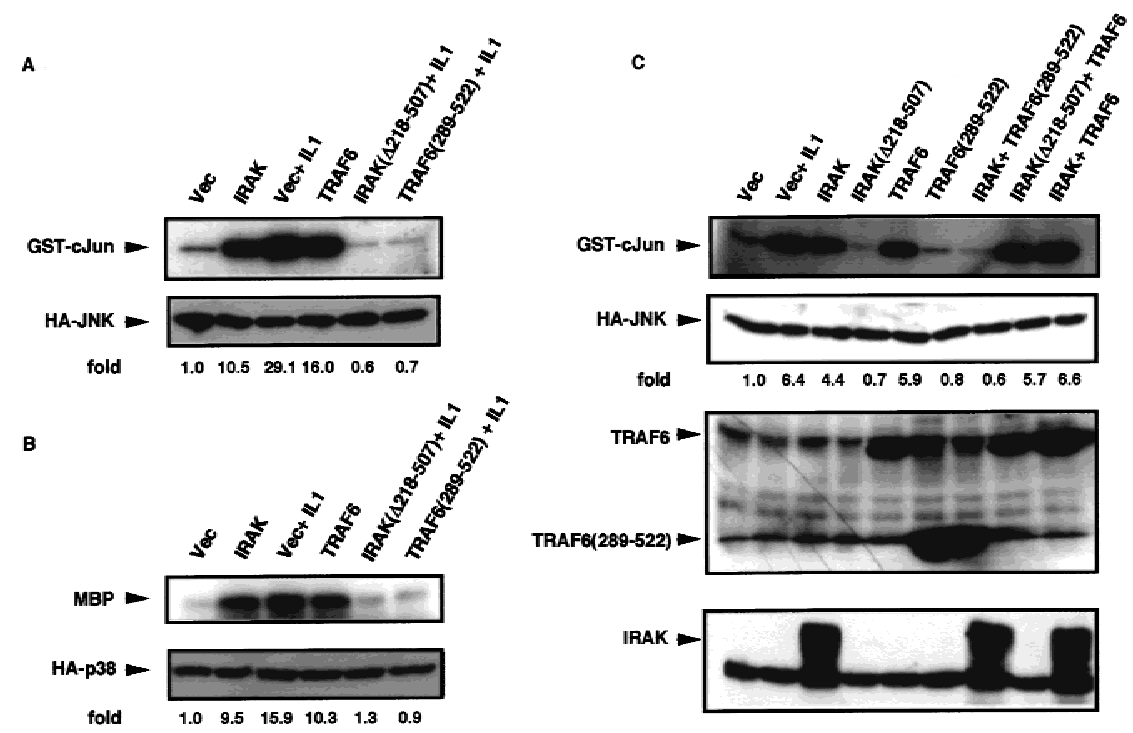

Figure 1. TRAF6 mediates JNK and p38 activation by IL-1. (A) HEK293 cells were cotransfected with HA-JNK1 (0.5 $\mu \mathrm{g} /$ plate) along with either an empty expression vector (Vec), IRAK or IRAK( $\Delta 218-507$ ) (100 ng/ plate each), or TRAF6 or TRAF6(289-522) (1 $\mu \mathrm{g} /$ plate each) expression vectors. Total DNA was kept constant (1.5 $\mu \mathrm{g} /$ plate) using empty expression vector. After $24 \mathrm{hr}$ the transfected cells were treated with IL-1 (10 $\mathrm{ng} / \mathrm{ml}$ ) for $30 \mathrm{~min}$ or left untreated. Cells were collected, lysed, and HA-JNK1 activity was determined by immunocomplex kinase assay with GST-cJun(1-79) as a substrate. Fold-increase in HA-JNK1 activity above the basal level in cells cotransfected with empty expression vector was determined by PhosphorImaging and normalized to the level of HA-JNK1 expression, determined by immunoblotting. (B) HEK293 cells were transfected as described above except that an HA-p38 $\alpha$ vector $(0.5 \mu \mathrm{g} /$ plate) was used instead of the HA-JNK1 vector. HA-p38 $\alpha$ activity was determined, as above, by immunocomplex kinase assay with myelin

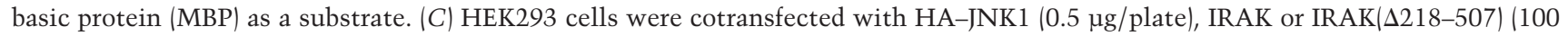
ng/plate each), TRAF6 or TRAF6(289-522) (1 $\mu$ g/plate each) expression vectors as indicated. After 24 hr some cultures were treated with IL-1 for $30 \mathrm{~min}$ and the rest left untreated. HA-JNK1 activity and expression were determined as described above. Expression of Flag-TRAF6, Flag-TRAF6(289-522), or IRAK was determined by immunoblotting.

downstream of IRAK in the pathway leading from IL-1R to JNK or p38. Accordingly, coexpression of IRAK and TRAF6 did not elicit a greater JNK activation response than either protein alone (Fig. 1C). Essentially identical results were obtained when activation of $\mathrm{p} 38$ or NF-кB were measured as endpoints (data not shown). Immunoblots indicated that the potent inhibitory effect of TRAF6(289-522) on JNK, p38 or NF-кB activation is not caused by nonspecific interference with IRAK, JNK1, or p38 $\alpha$ expression.

TRAF-FKBP12 chimeras can activate INK, p38, and $I K K$

TRAF2 and TRAF6 are recruited to the occupied TNF- $\alpha$ and IL-1 receptors through binding of different adapters, namely TRADD and IRAK, respectively, via their carboxy-terminal TRAF domains (Cao et al. 1996b; Hsu et al. 1996). Overexpression of either TRAF2 or TRAF6 may mimic ligand-induced signaling by causing their aggregation. In addition to mediating recruitment to the receptor complex the carboxy-terminal TRAF domain can engage in homotypic and heterotypic TRAF-TRAF interactions (Rothe et al. 1994; Cheng et al. 1995; Cao et al. 1996b). We therefore hypothesized that the aminoterminal halves of TRAF2 and TRAF6 are their effector domains, whereas the carboxy-terminal TRAF domain serves only as an oligomerization and receptor docking domain. To test this hypothesis we fused amino acids 1-303 of TRAF2 or 1-274 of TRAF6 to a threefold repeat of the immunophilin FKBP12 (Fig. 2A). Upon incubation with dimeric FKBP ligands, such as FK1012, chimeras that contain several FKBP repeats undergo extensive oligomerization (Spencer et al. 1993). Transient transfection of either TRAF2(1-303)-FKBP12 or TRAF6(1-274)FKBP12 vectors results in expression of proteins of the expected size at levels similar to those of the native proteins (Fig. 2B,C). In the absence of FK1012 either chimera had little effect on activity of either a coexpressed HAJNK1 protein (Fig. $2 \mathrm{~B}, \mathrm{C}$ ) or a $2 \times \mathrm{NF}-\mathrm{\kappa B}-\mathrm{LUC}$ reporter (Fig. 2D,E). However, incubation of cells expressing either TRAF-FKBP12 chimera with FK1012, but not FK506, resulted in large increases in either JNK or NF-кB activity (Fig. 2B-E). FK1012-induced oligomerization of either TRAF-FKBP12 chimera resulted in activation of IKK (Fig. 2F, data not shown), similar in magnitude to the effects of either wild-type TRAF2 or TRAF6 /data not shown). Oligomerization of a TRAF2-FKBP12 mutant that can not activate NF-кB (see below) failed to stimulate IKK activity (Fig. 2F, mR1-FKBP).

I-TRAF/TANK is a TRAF-interacting protein whose overexpression inhibits TNF- $\alpha$ signaling through binding to the TRAF domain of TRAF2 (Cheng and Baltimore 1996; Rothe et al. 1996). Overexpression of TANK/ I-TRAF had little effect on either JNK or NF-кB activation by TRAF2(1-303)-FKBP12 (Fig. 3) or TRAF6(1-274)FKBP12 (data not shown), whereas it abolished TRAF2 and strongly reduced TRAF6-induced JNK and NF-кB activation (Fig. 3; data not shown). Therefore the TRAFFKBP12 chimeras do not function through an interaction with the endogenous TRAF2 or TRAF6 proteins or through their indirect activation.

Mutations in the amino-terminal RING and Zn fingers attenuate INK and NF-кB activation

The results presented above strongly suggested that the 
Baud et al.

Figure 2. TRAF-FKBP12 chimeras activate JNK and NF- $\kappa$ B in response to dimerizer-induced oligomerization. (A) A diagram illustrating the domain structure of the two TRAF-FKBP12 fusion proteins. (B) HEK293 cells were transfected with HA-JNK1 (0.5 $\mu \mathrm{g} /$ plate) along with either empty expression vector or expression vectors for Flag-TRAF2 or Flag-TRAF2(1303)-FKBP12 (1 $\mathrm{\mu g} /$ plate each). Some of the transfected cells were treated with either TNF- $\alpha(15 \mathrm{ng} / \mathrm{ml})$ for $10 \mathrm{~min}$, or FK506 (0.5 $\mu \mathrm{M})$ or FK1012 (0.5 $\mu \mathrm{M})$ for $4 \mathrm{hr}$, as indicated. JNK activity was determined as described above. Expression of HAJNK1, Flag-TRAF2, or Flag-TRAF2/1303)-FKBP12 were examined by immunoblotting. Similar results were obtained using HeLa cells as recipients (data not shown). (C) Similar experiments to those described in $B$ were performed using FlagTRAF6 and Flag-TRAF6(1-274)-FKBP12 expression vectors. Where indicated, transfected cells were treated with IL-1 $(4 \mathrm{ng} / \mathrm{ml})$ for $10 \mathrm{~min}(D, E)$ NF-кB activation by TRAF2(1-303)-FKBP12 (D) or TRAF6(1-274)-FKBP12 (E) was measured by transfecting HEK293 cells with a $2 \times N F-\kappa B-L U C$ reporter $(0.5 \mu \mathrm{g} /$ plate $)$ and the indicated TRAF and TRAF-FKBP12 expression vectors (1 $\mu \mathrm{g} /$ plate). pRSVlacZ $(0.1 \mu \mathrm{g} /$ plate $)$ was included to normalize transfection efficiency. Cells were collected $6 \mathrm{hr}$ after the indicated treatments (as in B), which were initiated $24 \mathrm{hr}$ after transfection, and luciferase activity was determined. $(F)$ HeLa cells were transfected with Flag-IKK $\alpha(0.5 \mu \mathrm{g})$ and the indicated TRAF2-FKBP12 vectors. Where indicated, cells were treated with TNF- $\alpha$ for 5 min or FK1012 for $4 \mathrm{hr}$ before collection and lysis. Immunocomplex kinase assay was performed with GST-IкB $\alpha(1-54)$ as a substrate.
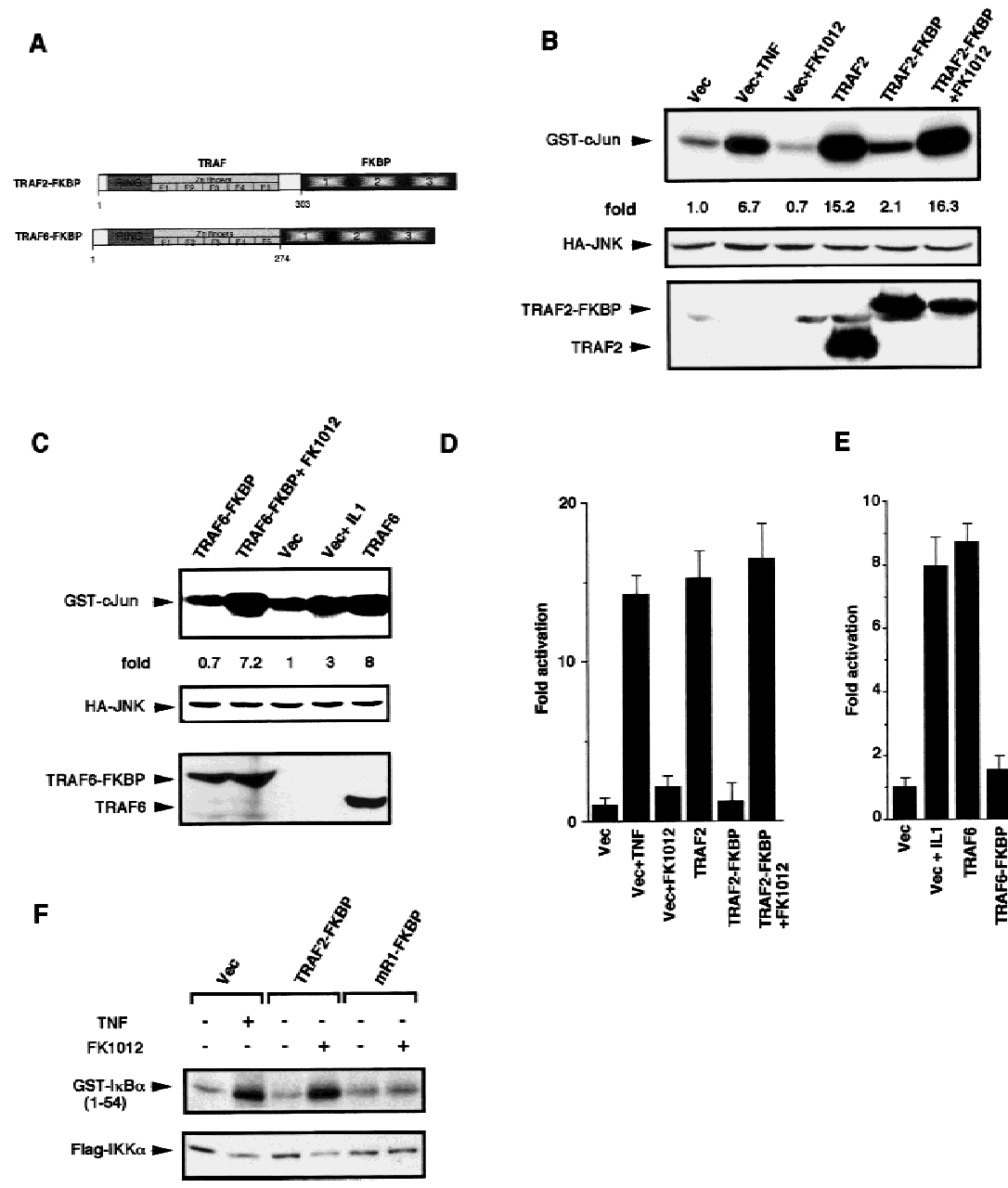

E

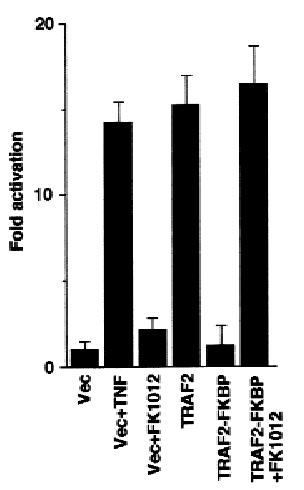

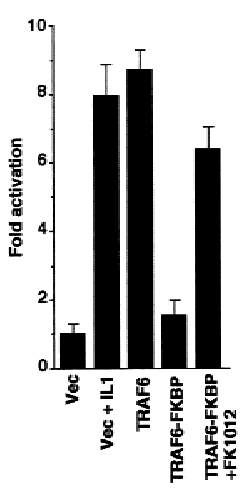

effector domains of TRAF2 and TRAF6 are located in their amino-terminal halves. As a further test of this possibility we generated a set of TRAF2 mutants in which the amino-terminal RING finger and the first three potential $\mathrm{Zn}$ fingers were rendered nonfunctional through substitution of cysteines, thought to be involved in metal binding, with serines (Fig. 4A). In mR1 C34 and $\mathrm{C} 37$ were replaced with serines, whereas in $\mathrm{mF} 1, \mathrm{mF} 2$, and $\mathrm{mF} 3 \mathrm{C} 107 / \mathrm{C} 112, \mathrm{C} 136 / \mathrm{C} 139$, and C163/C166, respectively, were substituted with serines.

When examined at low input $\mathrm{mR} 1$ and $\mathrm{mF} 1$ were defective in JNK activation, whereas $\mathrm{mF} 2$ and $\mathrm{mF} 3$ had wild-type activity (Fig. 4B, top). However when examined at higher input $\mathrm{mR} 1$ and $\mathrm{mF} 1$ were only partially defective in JNK activation (Fig. 4B, bottom). A mutant that completely lacks the RING finger, TRAF2(87-501), was inactive at all levels, as described previously (Liu et al. 1996). When examined at either low (data not shown) or high-input $\mathrm{mR} 1$ and $\mathrm{mF} 1$ failed to activate NF-кB, whereas mF2 had wild-type activity (Fig. 4C). Surprisingly, $\mathrm{mF} 3$ was 2.5 times more potent than wild-type TRAF2 in NF- $\mathrm{kB}$ activation (Fig. 4C). We also examined the ability of the various TRAF2 mutants to stimulate IKK activity by cotransfecting them with an HA-IKK $\beta$ vector (Zandi et al. 1997). Whereas neither $\mathrm{mR} 1$ nor $\mathrm{mF} 1$ activated IKK $\beta, \mathrm{mF} 2$ was as effective as wild-type TRAF2 (Fig. 4D). Consistent with its behavior in the reporter assay, $\mathrm{mF} 3$ activates IKK $\beta$ about twofold better than wild-type TRAF2 (Fig. 4D). mR1 was also inactive as an FKBP fusion protein (Fig. 2F).

\section{Oligomerization of TRAF2-FKBP12 in stably transfected cells activates the program of inflammation-induced genes}

To test whether the amino-terminal effector domain of 
A

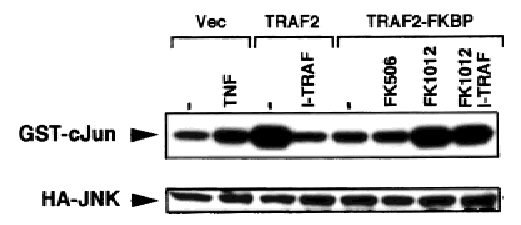

B

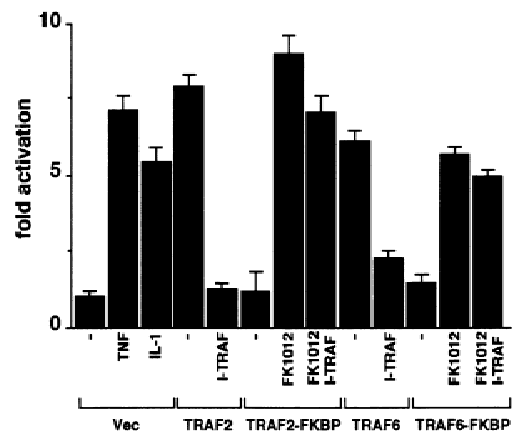

Figure 3. Activation of JNK and NF-кB by TRAF2-FKBP12 is insensitive to TANK/I-TRAF. (A) HEK293 cells were cotransfected with HA-JNK1 $(0.5 \mu \mathrm{g} /$ plate $)$ along with an empty expression vector, Flag-TRAF2 or Flag-TRAF2(1-303)-FKBP12 (500 ng/plate each) and I-TRAF (150 ng/plate) expression vectors as indicated. Cells were treated with either TNF- $\alpha$ for 15 min, or FK506 or FK1012 for $4 \mathrm{hr}$, as indicated, before being collected to measure HA-JNK1 activity and expression. $(B)$ HEK293 cells were transfected with $2 \times \mathrm{NF}-\mathrm{kB}-\mathrm{LUC}$ and RSVlac $Z$ reporters along with the indicated expression vectors and treated as in $A$. Luciferase activity was determined as described above.

TRAF2 is sufficient for triggering most of the physiological functions of TNF- $\alpha$ at the cellular level, we generated stably transfected clones of $\mathrm{HeLa}$ cells that express TRAF2(1-303)-FKBP12 at levels that are not much higher than those of endogenous TRAF2 (data not shown). Treatment of such cells with FK1012, but not FK506 (data not shown), resulted in efficient JNK and IKK activation similar in magnitude to the effects of TNF- $\alpha$ (Fig. 5A) and IL-1 (data not shown). Treatment of nontransfected cells with FK1012 had no effect on either protein kinase (data not shown). To examine whether dimerizer-induced clustering of the TRAF2(1-303)FKBP12 chimera induced the same gene expression program as induced by TNF- $\alpha$ or IL-1, we extracted total cytoplasmic RNA from cells stably expressing this chimera that were either cultured in growth medium alone or treated with FK1012 (4 hr). We also prepared RNA samples from untreated, TNF- $\alpha$ (7 hr)-, IL-1 (7 hr)-, or FK1012 (4 hr)-treated parental HeLa cells. Poly(A) ${ }^{+}$RNA was isolated and used to generate total ${ }^{32} \mathrm{P}$-labeled cDNA probes that were hybridized to membranes containing 597 spotted DNA fragments derived from different human genes. Exposure to TNF- $\alpha$ or IL- 1 induced the expression of five of these genes by more than three- to fourfold (Fig. 5B). These genes code for the chemokines MCP-1, MIP-2a, and IL-8, the cytokine IL-6 and the ad- hesion molecule ICAM-1. Treatment of the TRAF2(1303)-FKBP12-expressing cells with FK1012 induced the same set of genes as induced by TNF- $\alpha$ or IL-1. Moreover, none of the 590 genes (of which only 4 are shown in the Fig. $5 \mathrm{~B}$ ) that were refractory to TNF- $\alpha$ and IL- 1 was induced by treatment of TRAF2-FKBP12-expressing cells with FK1012 (Fig. 5B; data not shown). Treatment of nontransfected HeLa cells with FK1012 did not induce any TNF- $\alpha$ - and IL-1-responsive genes (data not shown).

\section{Dimerizer-induced interaction of TRAF-FKBP12 chimeras with MEKK1}

A member of the MAPKKK family, NIK, was suggested to mediate TNF- $\alpha$ - and IL-1-induced NF- $\mathrm{B}$ activation (Malinin et al. 1997). NIK was isolated as a TRAF2-interacting protein. However, NIK interacts with almost all of known TRAF proteins, regardless of their ability to activate NF-кB (Song et al. 1997; V. Baud, unpubl.). Furthermore, signaling incompetent mutants of TRAF2 or TRAF6 do not exhibit any reduction in their ability to interact with NIK (V. Baud, unpubl.). Yet, overexpressed NIK activates NF- $\mathrm{B}$ and catalytically inactive NIK(AA) mutant can block TNF- $\alpha$ - and IL-1-induced NF-кB activation (Malinin et al. 1997). Another MAPKKK, MEKK1 was suggested to transduce the effect of TNF- $\alpha$ and IL-1 to the JNK and p38 cascades (Minden et al. 1995; Liu et al. 1996; Xia et al. 1998). MEKK1 was also suggested to be involved in NF-кB activation (Lee et al. 1997). Another MAPKKK suggested to be involved in TNF- $\alpha$-induced JNK activation is ASK1 (Ichijo et al. 1997).

We examined whether the TRAF-FKBP12 chimeras interact with either of these MAPKKKs and other signaltransducing proteins known or thought to be involved in TNF- $\alpha$ or IL-1 signaling. As observed by others (G. Crabtree, pers. comm.) we found that within $1 \mathrm{hr}$ of FK1012 treatment the TRAF-FKBP12 chimeras formed aggregates that could be sedimented from cell lysates by centrifugation. These aggregates were insoluble in nondenaturing buffers and therefore it was impossible to use conventional immunoprecipitation procedures to examine the interaction of any protein with the oligomerized TRAF-FKBP12 chimeras. To circumvent this problem we took advantage of the ability of the oligomerized TRAF-FKBP12 chimeras to form insoluble aggregates and examined whether coexpressed signal transducing proteins cosedimented with TRAF2(1-303)-FKBP12 upon FK1012 addition. Whereas epitope-tagged NIK, ASK1, GCK, and MEKK2 remained soluble after coexpression with TRAF2(1-303)-FKBP12 and FK1012 treatment, full-length MEKK1 was rendered insoluble by this treatment (Fig. 6). If expressed in the absence of TRAF2(1-303)-FKBP12, MEKK1 remained soluble even after incubation with FK1012. Interestingly, truncated MEKK1 polypeptides produced by intracellular proteolysis (Cardone et al. 1997; Widmann et al. 1998) remained soluble and did not cosediment with oligomerized TRAF2(1-303)-FKBP12. To further investigate which region of MEKK1 is involved in the interaction with TRAF2(1-303)-FKBP12, we coexpressed the chimera 
Baud et al.

Figure 4. Mutations within the amino-terminal effector domain of TRAF2 differentially affect JNK and IKK activation. (A) Schematic representation of TRAF2 mutants. The numbers below the diagram refer to amino acids positions. F1-5 denote the five $\mathrm{Zn}$ fingers. The domains in which pairs of cysteine residues were replaced with serines are indicated by black boxes (mR1: S34/37; mF1: S107/112; mF2: S136/139; and mF3: S163/166). (B) JNK activation. HEK293 cells were cotransfected with HA-JNK1 and either an empty vector or expression vectors encoding wild-type or mutant versions of TRAF2, used at either low $(0.2 \mu \mathrm{g} /$ plate; top two panels) or high $(1 \mu \mathrm{g} /$ plate; bottom two panels) input levels. After $24 \mathrm{hr}$ cells were collected and HA-JNK1 activity and expression were determined. TRAF expression was also determined. (C) NF-kB activation. HEK293 cells were cotransfected with $2 \times N F-$ $\kappa \mathrm{B}-\mathrm{LUC}$ and pRSV-lacZ reporters and either an empty vector or expression vectors for wildtype and mutant TRAF2 proteins as indicated $(1 \mu \mathrm{g} / \mathrm{plate})$. Cells were collected, and luciferase activity and TRAF expression were determined. (D) IKK activation. HEK293 cells were cotransfected with HA-IKK $\beta(0.25 \mu \mathrm{g} /$ plate $)$ and either an empty vector or expression vectors for wild-type and mutant TRAF2 proteins (1 $\mathrm{\mu g} /$ plate). Some transfectants were treated with TNF- $\alpha(15 \mathrm{ng} / \mathrm{ml})$ for $10 \mathrm{~min}$. Immunocomplex kinase assay was performed with GST-IкB $\alpha(1-54)$ as a substrate. HA-IKK $\beta$ and TRAF expression were determined by immunoblotting.

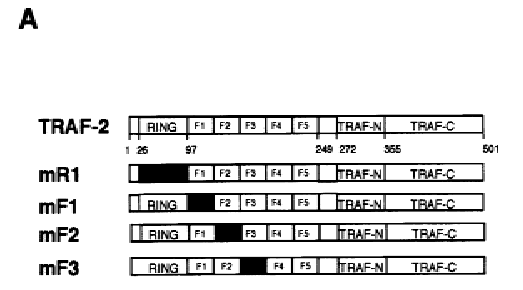

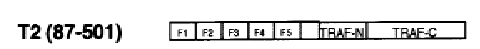
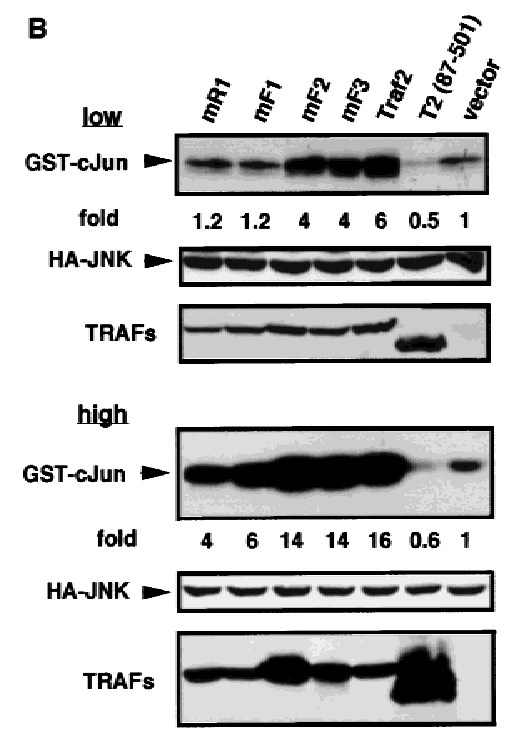

C
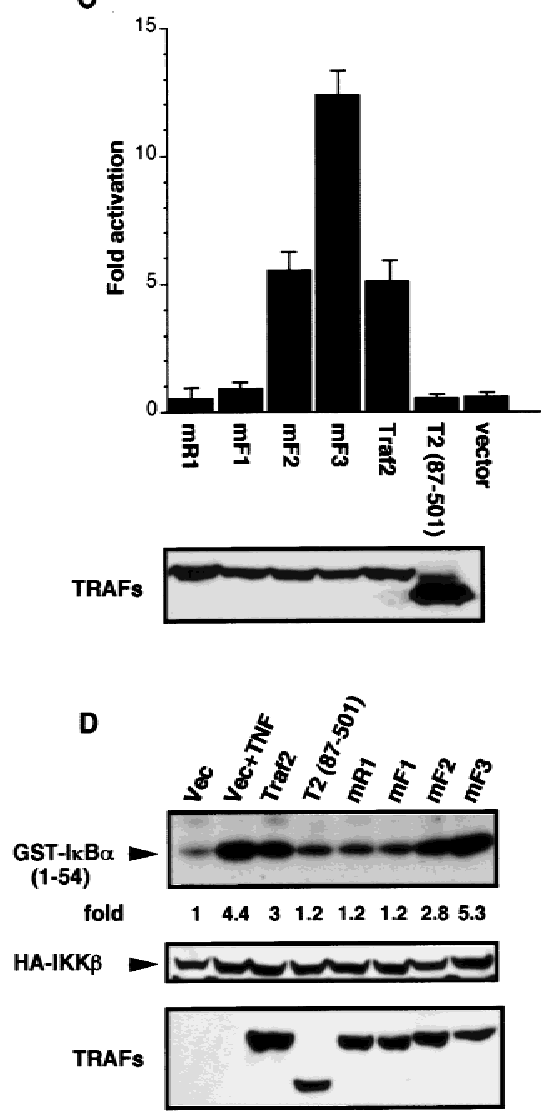

with either full-length MEKK1 or two deletion mutants, $70 \mathrm{~K}$ MEKK $1 \Delta \mathrm{N}$ and $35 \mathrm{~K}$ MEKK $1 \Delta \mathrm{N}$, which encode the carboxy-terminal 672 and 321 residues of MEKK1, respectively. Whereas full-length MEKK1 cosedimented with TRAF2(1-303)-FKBP12 after FK1012 treatment, the truncation mutants remained soluble (Fig. 6). To further examine the physiological relevance of this interaction we coexpressed MEKK1 with mutant versions of TRAF2(1-303)-FKBP12 that either contain a nonfunctional amino-terminal RING finger (mR1-TRAF2FKBP12) or completely lack this part of the protein [TRAF2(100-303)-FKBP12; indicated as $\triangle T R A F 2$ in the Fig. 6]. Although both mutants were rendered insoluble after FK1012 treatment, mR1-TRAF2-FKBP12 was considerably less effective in coprecipitating MEKK1 in comparison to wild-type TRAF2-FKBP12, whereas a very small fraction of MEKK1, if any, cosedimented with TRAF2(100-303)-FKBP12 (Fig. 6). Interestingly, coexpression of wild-type TRAF2-FKBP12 enhanced MEKK1 proteolysis, whereas coexpression of mR1-TRAF2FKBP12 or TRAF2(100-303)-FKBP12 decreased the extent of MEKK1 proteolysis. These observations are consistent with previous reports according to which cell stimulation enhanced MEKK1 proteolysis (Cardone et al. 1997; Widmann et al. 1998).
TNF- $\alpha$ activates MEKK1 and enhances its binding to TRAF2

The results described above suggest that MEKK1 is one of the effectors through which TRAF2 activates downstream kinases. To further investigate the role of MEKK1 in TNF- $\alpha$ signaling we examined the effect of TNF- $\alpha$ on the interaction between TRAF2 and MEKK1. HEK293 cells were transfected with either a wild-type TRAF2 or a TRAF2(87-501) expression vector in the absence or presence of an MEKK1 vector. Cells were either left untreated or were stimulated with TNF- $\alpha$ and the interaction between MEKK1 and TRAF2 or TRAF2(87-501) examined by immunoprecipitation. Cell stimulation with TNF- $\alpha$ resulted in a large increase in the interaction between MEKK1 and wild-type TRAF2, whereas no considerable interaction was observed between MEKK1 and TRAF2 (87-501) in the absence or presence of TNF- $\alpha$ (Fig. 7A). In addition, cell stimulation with TNF- $\alpha$ substantially increased the extent of MEKK1 autophosphorylation, only which coexpressed with wild-type TRAF2 (Fig. 7A). In nontransfected cells, stimulation with TNF- $\alpha$ increased both the autokinase activity of MEKK1 and its ability to phosphorylate JNKK1 (Fig. 7B). Expression of catalytically inactive MEKK1 inhibited the 
A
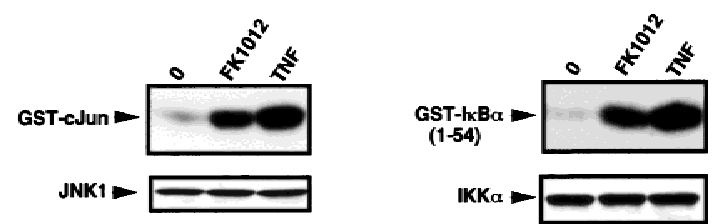

B

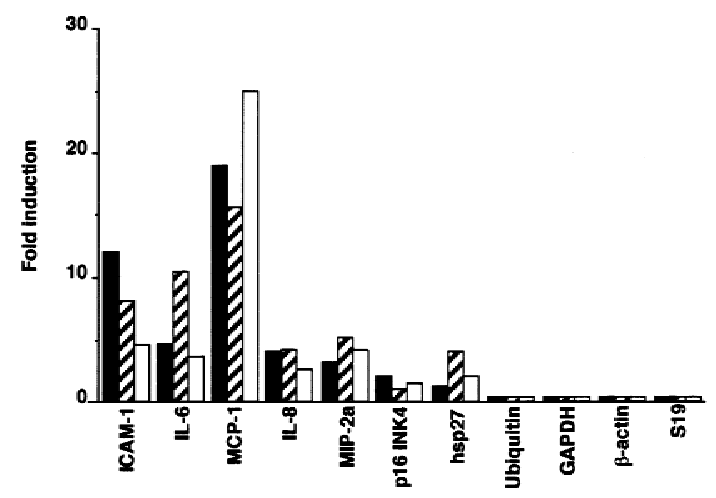

Figure 5. Treatment of HeLa cells stably expressing TRAF2FKBP12 with FK1012 activates the inflammation-induced gene expression program. (A) Treatment of HeLa cells that stably express TRAF2(1-303)-FKBP12 with FK1012 activates JNK and IKK. Endogenous JNK1 (left) or IKK $\alpha$ (right) was immunoprecipitated from untreated or cells treated with either TNF- $\alpha$ (15 $\mathrm{ng} / \mathrm{ml}$ for $10 \mathrm{~min})$ or FK1012 (0.5 $\mathrm{MM}$ for $4 \mathrm{hr})$. JNK and IKK activity were determined by immunocomplex kinase assays with GST-cJun(1-79) and GST-IкB $\alpha(1-54)$ as substrates, respectively. Immunoprecipitated JNK1 and IKK $\alpha$ proteins were detected by immunoblotting. (B) Oligomerization of TRAF2(1303)-FKBP12 induces the same gene expression program as TNF- $\alpha$ or IL-1. Membranes containing an array of 597 spotted cDNA fragments derived from different human genes were hybridized to ${ }^{32} \mathrm{P}$-labeled cDNA probes derived from poly $(\mathrm{A})^{+}$RNA samples prepared from either parental HeLa cells that were either untreated or treated with either TNF- $\alpha$ (solid bars; $15 \mathrm{ng}$ / $\mathrm{ml}$ ) or IL-1 (hatched bars; $4 \mathrm{ng} / \mathrm{ml}$ ) for $7 \mathrm{hr}$, or from HeLa cells stably expressing TRAF2(1-303)-FKBP12 that were either untreated or treated with FK1012 (open bars; $0.5 \mu \mathrm{M}$ for $4 \mathrm{hr}$ ). The fold-increase in gene expression above the level in untreated parental or transfected cells was determined by PhosphorImaging and a series of Excel-based macros as described in Materials and Methods. Data are averages of two completely independent experiments. Only 4 of the 590 genes whose expression was not induced by TNF- $\alpha$, IL-1, or FK1012 are included. Treatment of parental HeLa cells with FK1012 did not result in gene induction (data not shown).

ability of both TRAF2 and TRAF2-FKBP to activate JNK (Fig. 7C). Previously the same mutant was found to inhibit TNF- $\alpha$-induced JNK activation (Liu et al. 1996). These results strongly implicate MEKK1 as a downstream effector of TRAF2.

\section{Discussion}

Although TNF- $\alpha$ and IL-1 or their receptors bear no biochemical and structural resemblance, they elicit similar biological effects (Tracey and Cerami 1993; Dinarello
1994). This is largely because both TNF- $\alpha$ and IL-1 are potent activators of AP-1 and NF- $\mathrm{B}$, which mediate many of their effects (Barnes and Karin 1997). Activation of AP-1 and NF- $\mathrm{BB}$ can be attributed to the recruitment of two similar signaling proteins, TRAF2 and TRAF6, respectively, to the TNF- $\alpha$ and IL-1 receptors. TRAF2 and TRAF6 are members of a growing family of signal transducers related by a conserved carboxy-terminal TRAF domain (Cao et al. 1996b). Except for TRAF6, which is exclusively involved in IL-1 signaling (Cao et al. 1996b), most other TRAFs are signal transducers for members of the TNF/TNFR superfamilies (Rothe et al. 1995; Duckett et al. 1997; Arch et al. 1998). The results described above explain how TRAF2 and TRAF6, and by analogy other TRAF proteins, transduce signals generated by receptor occupancy to downstream responses. According to these results the conserved carboxy-terminal TRAF domain is likely to function as an oligomerization domain whose major role is to induce clustering of the more variable amino-terminal effector domain. Regulated clustering of the amino-terminal effector domains of either TRAF2 or TRAF6, through fusion to a threefold FKBP12 repeat and incubation with the dimerizer FK1012 (Spencer et al. 1993), is sufficient for activating all of the downstream protein kinases that transduce the TNF- $\alpha$ and IL- 1 signals to AP- 1 and NF- $\kappa$ B and for induction of the same spectrum of target genes normally induced by TNF- $\alpha$ or IL- 1 .

Overexpressed native TRAF2 or TRAF6 can activate JNK, p38, and IKK, in the absence of extracellular stimuli. We explain these results by postulating that overexpression of TRAF2 or TRAF6 results in their oligomerization, thereby mimicking recruitment to ligand-oligomerized receptors (Heldin 1995). Because the carboxy-terminal TRAF domain is involved in homotypic and heterotypic TRAF-TRAF interactions (Rothe et al. 1994; Cheng et al. 1995), it seemed likely that one of its more important roles is to cause oligomerization of TRAF2 or TRAF6. It therefore followed that the effector functions of TRAF2 or TRAF6 reside within their aminoterminal domains. This hypothesis was tested by fusing these domains to a threefold repeat of the immunophilin FKBP12 and induction of oligomerization with the dimerizer FK1012 (Spencer et al. 1993). Despite the absence of the carboxy-terminal TRAF domain, both TRAF-FKBP12 chimeras were capable of JNK, p38, IKK, and NF- $\kappa$ B activation after treatment with FK1012. Importantly, FK1012 treatment of HeLa cells that stably express TRAF2(1-303)-FKBP12 induced the same set of target genes whose expression is normally induced by TNF- $\alpha$ or IL- 1 . These genes code for the chemokines MCP-1, MIP-2a, and IL-8, the cytokine IL-6 and the adhesion molecule ICAM-1. As discussed (Barnes and Karin 1997), these and similar molecules (whose cDNAs were not part of the microarray we used) are instrumental in mediating the proinflammatory activity of TNF- $\alpha$ and IL-1. In addition, MCP-1, IL-8, IL-6, and ICAM-1 promoters contain functional AP-1 and NF- $\kappa$ B sites (Dendorfer et al. 1994; Chen and Manning 1995; Farina et al. 1997; Martin et al. 1997; Roger et al. 1998). Further 
Figure 6. Oligomerization-induced interaction of TRAF2-FKBP12 with MEKK1. HEK293 cells were transfected with $0.4 \mu \mathrm{g}$ of different expression vectors encoding wild-type or mutant versions of TRAF2-FKBP12 chimeras and different MAPKKKs (MAP3K; MEKK1, MEKK2, ASK1, NIK) or STE20-like kinases (MAP4K; GCK), as indicated. The transfected cultures were left untreated or treated with FK1012 (0.5 $\mu \mathrm{M}$ for $4 \mathrm{hr}$ ) before lysis in nondenaturing buffer. After centrifugation the dissolved insoluble $(\mathrm{P})$ and soluble $(\mathrm{S})$ fractions were separated by $7.5 \%$ SDS-polyacrylamide gel. MEKK1, ASK, GCK, and NIK were detected by immunoblotting with antibody to their amino-terminal Xpress tag. The $35 \mathrm{~K}$ and $70 \mathrm{~K}$ MEKK1 $\Delta \mathrm{N}$ truncation mutants and MEKK2 were detected with anti-MEKK1 and MEKK2, respectively. The different TRAF2-FKBP12 chimeras were detected with an antibody to their amino-terminal Flag tag. Equal loading of the lanes was controlled by probing the same blots with an actin antibody.

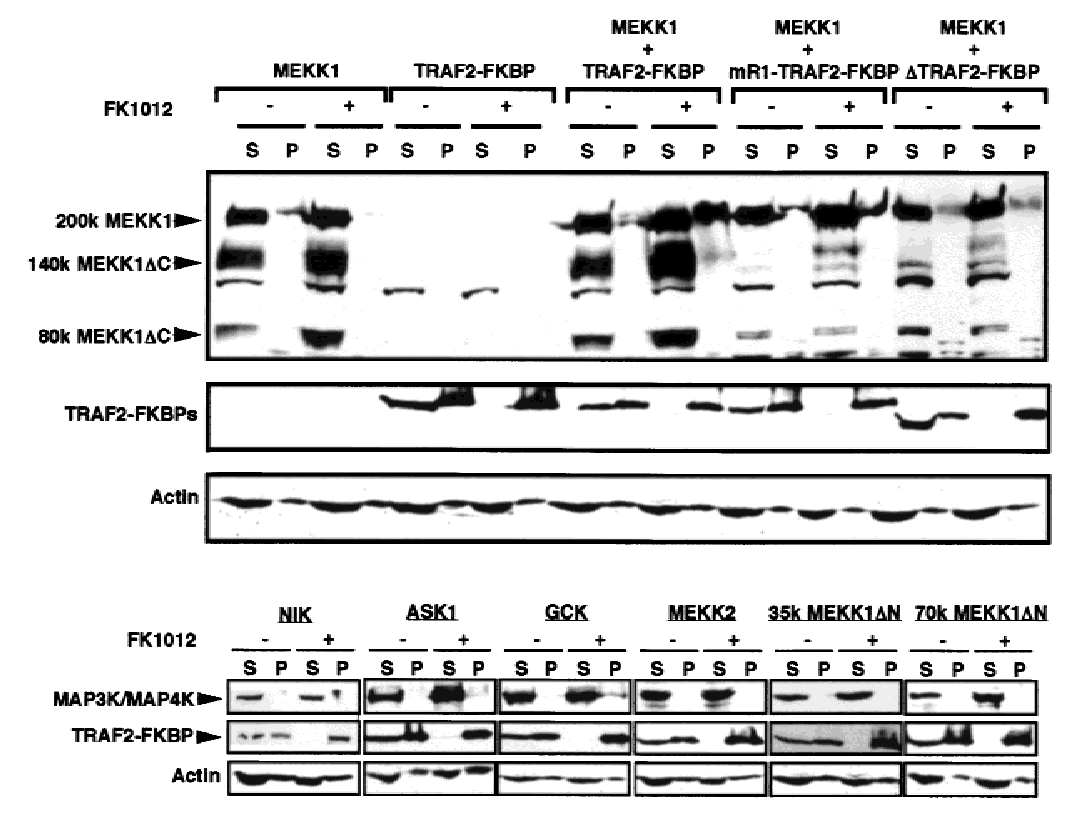

also found that MEKK1 is involved in TNF- $\alpha$-mediated ERK activation (Y. Xia, unpubl.). More recently, MEKK1 was also proposed to be involved in NF- $\mathrm{KB}$ activation (F.S. Lee et al. 1997; Yin et al. 1998). Although MEKK1 overexpression causes IKK activation (Lee et al. 1998), this effect is weaker than the effect on JNK activity (Karin and Delhase 1998). Also the mR1-TRAF2 mutant which is partly defective in MEKK1 binding has diminished ability to activate JNK but is completely unable to activate IKK or NF-кB. It is therefore possible that MEKK1 activation can contribute to NF- $\mathrm{KB}$ activation via an IKK-independent mechanism. For instance both p38 and ERK may be involved in stimulation of NF- $\mathrm{kB} /$ p65 transcriptional activity in TNF- $\alpha$-treated cells (Vanden Berghe et al. 1998). Although MEKK1 is probably not the sole effector that is activated by the TRAF2 aminoterminal domain, these results are consistent with the results of gene targeting experiments. Cells isolated from TRAF2 knockout mice are completely deficient in TNF$\alpha$-mediated JNK activation but are compromised only partially in NF-kB activation (S.Y. Lee et al. 1997; Yeh et al. 1997). One explanation for the partial defect in NF-кB activation is that another TRAF protein, possibly TRAF5 (Nakano et al. 1996), may compensate for the loss of TRAF2. Alternatively, a weak effect of MEKK1 on IKK may result in nuclear translocation of only a small fraction of NF-кB complexes, whose transcriptional activity could be enhanced greatly via $\mathrm{p} 38$ and ERK. Together, these pathways will cause a large increase in NF- $\mathrm{kB}$ transcriptional activity in TRAF overexpressing cells. Yet, in the absence of TRAF2, TNF- $\alpha$ can activate NF- $\mathrm{kB}$ via MEKK1-independent mechanisms.

TRAF2 was found previously to interact with the germinal center kinase (GCK) and NIK, protein kinases involved in JNK and NF-кB activation (Malinin et al. 1997; Yuasa et al. 1998). Although catalytically inactive NIK blocks NF-кB activation (Malinin et al. 1997; Song et al. 
A

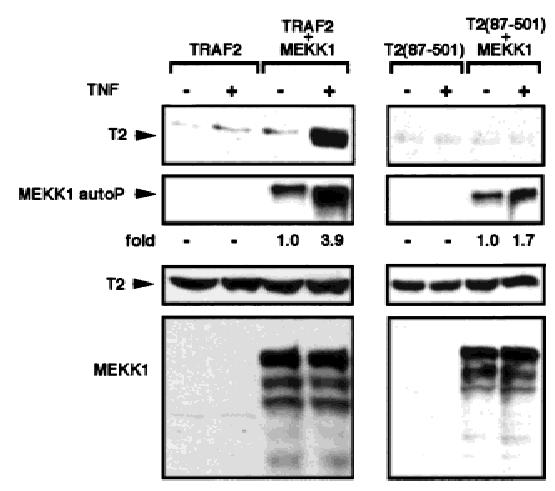

B
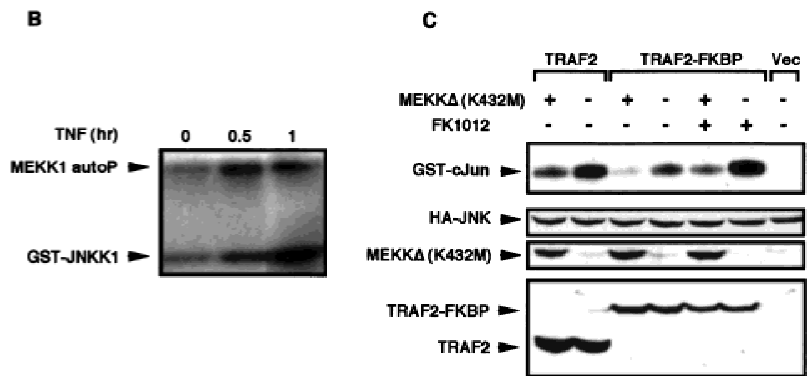

Figure 7. TNF- $\alpha$ activates MEKK 1 and enhances its binding to TRAF2. (A) TNF- $\alpha$-dependent association of TRAF2 with MEKK1 and increase of MEKK1 autokinase activity. HEK293 cells were cotransfected with Flag-TRAF2 (50 ng DNA/plate) along with either an empty vector or Xpress-MEKK1 (100 ng DNA/plate). Lysates prepared from untreated or TNF- $\alpha$-treated cells $(10 \mathrm{ng} / \mathrm{ml}, 4 \mathrm{~min})$ were immunoprecipitated with antiMEKK1. Coprecipitating Flag-TRAF2 was detected by immunoblot analysis. MEKK1 autophosphorylation was determined by immunocomplex kinase assay without exogenous substrate. Fold increase in TNF- $\alpha$-induced MEKK1 autophosphorylation was determined by PhosphorImaging. (B) Activation of endogenous MEKK1 by TNF- $\alpha$. HeLa cells were treated with TNF- $\alpha$ for $30 \mathrm{~min}, 1 \mathrm{hr}$, or left untreated. Endogenous MEKK1 was immunoprecipitated from $1 \mathrm{mg}$ of total cell lysates and its autokinase activity and ability to phosphorylate catalytically inactive JNKK1 were determined by immunocomplex kinase assay. (C) Inactive MEKK1 mutant inhibits JNK activation by TRAF2 and TRAF2-FKBP12. HEK293 cells were cotransfected with HA-JNK1 (0.4 $\mu \mathrm{g}$ DNA/plate), along with an empty expression vector, Flag-TRAF2 (50 ng DNA/plate), or FlagTRAF2-FKBP12 (100 ng DNA/plate) and MEKK1 (K432M) (2 $\mu \mathrm{g}$ DNA/plate) expression vectors as indicated. Cells were left untreated or treated with FK1012 for $4 \mathrm{hr}$, as indicated, before being collected to measure HA-JNK1 activity and expression.

1997), its binding to TRAF2 is mediated by the carboxyterminal TRAF domain, which is absent from the chimeric protein. Therefore, the ability of NIK to bind to the carboxy-terminal TRAF domains of TRAF2 or TRAF6 (Malinin et al. 1997; Song et al. 1997) is not crucial for their signaling activity. Furthermore, NIK binds indiscriminately to most TRAF proteins regardless of their ability to trigger NF- $\mathrm{B}$ activation (Song et al. 1997). Importantly, NIK binds to TRAF3 and the mR1 and mF1 mutants of TRAF2 (V. Baud, unpubl.), all of which cannot activate NF-кB. Furthermore, binding of NIK to TRAF2 and its catalytic activity are not stimulated by TNF- $\alpha$ (V. Baud, unpubl.). Overexpressed NIK was found to associate with IKK $\alpha$ or IKK $\beta$ (Régnier et al. 1997; Woronicz et al. 1997), but it is not an integral part of the native IKK complex (DiDonato et al. 1997; Rothwarf et al. 1998). Thus, although NIK seems to be involved in NF-кB activation its exact function and relationship to TNF- $\alpha$ or IL-1 signaling remain enigmatic. GCK binding to TRAF2 is also mediated via the TRAF domain rather than the amino-terminal effector domain (Yuasa et al. 1998). In addition to its role in oligomerization, the carboxy-terminal TRAF domain through interaction with other protein kinases may facilitate the activation of proteins that directly interact with the amino-terminal effector domain of TRAF2, one of which seems to be MEKK1. In this respect, TRAF2 and other family members may be regarded as molecular scaffolds (Faux and Scott 1996).

In summary, binding of TNF- $\alpha$ and IL- 1 to their respective receptors induces recruitment of TRAF2 or TRAF6, respectively, to the activated receptors as well as receptor clustering. This results in TRAF oligomerization, which stabilizes or enhances the interaction of the amino-terminal TRAF effector domains with at least two effectors. One effector contributes mostly to MAPK activation, which seems to be MEKK1, and the other contributes mostly to IKK activation. Direct induction of TRAF2 or TRAF6 oligomerization bypasses the initial steps in TNF- $\alpha$ and IL-1 signaling, resulting in effective dimerizer-dependent IKK and MAPK activation and induction of NF- $\mathrm{B}$ and AP-1 target genes.

\section{Materials and methods}

\section{Cell culture and cytokines}

HEK293 or HeLa cells were maintained as described (Hsu et al. 1995). Stably transfected HeLa cells expressing TRAF2(1-303)FKBP12 were established by standard procedures using $\mathrm{Neo}^{\mathrm{r}}$ as a selection marker and G418. Positive clones were identified by immunoblot analysis. Human recombinant IL- $1 \alpha$ and TNF- $\alpha$ were provided by Dainppon Pharmaceutical Co. and Chiron, Inc., respectively.

\section{Expression vectors and transfections}

HA-JNK1, HA-p38 $\alpha$, Flag-IKK $\alpha$, HA-IKK $\beta$, and $2 \times$ NFwere described (Dérijard et al. 1994; Minden et al. 1994; Liu et al. 1996; DiDonato et al. 1997; Zandi et al. 1997). Expression vectors for IRAK, TRAF6, TRAF6(289-522), I-TRAF, NIK, GCK, ASK1, MEKK1 full-length and deletion mutants and MEKK2 were also described (Lange-Carter et al. 1993; Katz et al. 1994; Blank et al. 1996; Cao et al. 1996a,b; Rothe et al. 1996; Ichijo et al. 1997; Malinin et al. 1997; Natoli et al. 1997; Xia et al. 1998). Kinase-defective IRAK was generated by deleting IRAK coding sequences from amino acid 218 to $507 . \mathrm{mR} 1, \mathrm{mF} 1$, $\mathrm{mF} 2$, and $\mathrm{mF} 3$ TRAF2 mutants were generated by substituting cysteines $34 / 37,107 / 112,136 / 139$, and 163/166 in wild-type TRAF2 with serines, respectively, using site-directed mutagenesis. TRAF-FKBP12 expression vectors were generated by standard recombinant DNA procedures and details are available upon request. 
For transfections, $3 \times 10^{5}$ cells in $35-\mathrm{mm}$ dishes were transfected with 1.5-2.0 $\mathrm{\mu g}$ of DNA using lipofectamine (GIBCO BRL) as described (Minden et al. 1994). Luciferase activity was determined as described (Hsu et al. 1995) and normalized per $\beta$-galactosidase expression from a cotransfected lacZ reporter.

\section{Immunoblotting}

Cell lysates (20 $\mu$ g of protein) were resolved on $7.5 \%-10 \%$ SDSpolyacrylamide gels and transferred to Immobilon $\mathrm{P}$ membranes (Millipore). After blocking with 5\% skim milk in PBS-T (PBS with $0.1 \%$ Tween 20 ) for $1 \mathrm{hr}$, the membranes were probed with either HA (Pharmingen), Xpress (Invitrogen), M2 (Sigma), MEKK1 C-22 (Santa Cruz), MEKK2 (gift of B. Su, M.D. Anderson Cancer Center, Houston, TX), JNK1 333.8 (Pharmingen), IKK $\alpha$ (Pharmingen), or IRAK (Santa Cruz) antibodies. Subsequent Western blotting analyses were performed as described (Hsu et al. 1995).

\section{Kinase assays}

Transfected cells were collected in $200 \mu$ of M2 lysis buffer 24 hr after transfection (Minden et al. 1994). HA-JNK1, HA-p38 $\alpha$, Flag-IKK $\alpha$, or HA-IKK $\beta$ was immunoprecipitated with HA or $\mathrm{M} 2$ antibodies, as required, and their kinase activities determined using $2 \mu \mathrm{g}$ of GST-cJun(1-79), myelin basic protein (MBP), or GST-IкB $\alpha(1-54)$, as substrates (Dérijard et al. 1994, 1995; DiDonato et al. 1997; Zandi et al. 1997). Fold activation of HA-JNK1, HA-p38 $\alpha$, HA-IKK $\beta$, and Flag-IKK $\alpha$ was determined by PhosphorImaging and normalized to their expression levels.

\section{Gene expression microarray}

Total cytoplasmic RNA was prepared (Maniatis et al. 1989). Poly $(\mathrm{A})^{+}$RNA was isolated using Oligotex resin according to the manufacturer's instructions (Qiagen). Atlas Human cDNA Expression Array (Clontech) containing 597 spotted cDNA fragments derived from different human genes was probed with ${ }^{32} \mathrm{P}$-labeled cDNA probes generated from $1.5 \mu \mathrm{g}$ of poly $(\mathrm{A})^{+}$ RNA, hybridized, and washed as recommended by the manufacturer. Image data were collected by PhosphorImaging. Hit picking and subsequent analysis were performed using a series of Excel-based macros developed at Signal Pharmaceuticals.

\section{Coprecipitation of proteins with TRAF-FKBP12 chimeras}

After transfection, HEK293 cells were treated or not with FK1012 $(0.5 \mu \mathrm{M})$ for $4 \mathrm{hr}$, collected, and lysed in $200 \mu \mathrm{l}$ of nondenaturing lysis buffer ( $25 \mathrm{~mm}$ HEPES at pH 7.7, $300 \mathrm{~m} \mu \mathrm{NaCl}$, $1.5 \mathrm{~mm} \mathrm{MgCl}_{2}, 0.2 \mathrm{~mm}$ EDTA, 0.5\% Triton X-100, 2 mM DTT, $1 \mathrm{mM}$ PMSF). After centrifugation at $10,000 \mathrm{~g}$ for $10 \mathrm{~min}$ at $4^{\circ} \mathrm{C}$, the supernatant was recovered and the pellet was resuspended in $200 \mu \mathrm{l}$ of $2 \times$ Laemmli buffer. One-tenth of both soluble and insoluble fractions was fractionated on a $7.5 \%$ SDS-polyacrylamide gel, transferred to Immobilon P membrane and Western blotted.

\section{Acknowledgments}

We thank Z. Wu and G. Natoli for helpful discussions and various constructs; Z. Cao, M. Rothe, and D.V. Goeddel for IRAK, TRAF6, and I-TRAF plasmids; S.L. Schreiber and G. Crabtree for the generous gifts of the FKBP12 plasmid and FK1012; D. Hecht for developing software for identification and hit-picking from the gene expression microarray. We are grateful to B. Thompson for excellent manuscript assistance preparation. This work was supported by postdoctoral fellowships from la Ligue Nationale Contre le Cancer (V.B.) and Human Frontier Science Program Organization (V.B.), and the Arthritis Foundation (Z.G.L.) and grants from the National Institutes of Health (DK38527-11, ES04151-13, AI43477-01). M.K. is the Frank and Else SchillingAmerican Cancer Society Research Professor.

The publication costs of this article were defrayed in part by payment of page charges. This article must therefore be hereby marked 'advertisement' in accordance with 18 USC section 1734 solely to indicate this fact.

\section{References}

Arch, R.H., R.W. Gedrich, and C.B. Thompson. 1998. Tumor necrosis factor receptor-associated factors (TRAFs) - A family of adapter proteins that regulates life and death. Genes \& Dev. 12: 2821-2830.

Baeuerle, P.A. and T. Henkel. 1994. Function and activation of $\mathrm{NF}-\mathrm{kB}$ in the immune system. Annu. Rev. Immunol. 12: $141-179$.

Barnes, P.J. and M. Karin. 1997. Nuclear factor-кB-A pivotal transcription factor in chronic inflammatory diseases. New Engl. J. Med. 336: 1066-1071.

Beg, A.A. and A.S. Baldwin, Jr. 1993. The IкB proteins: Multifunctional regulators of Rel/NF- $\mathrm{B}$ transcription factors. Genes \& Dev. 7: 2064-2070.

Blank, J.L., P. Gerwins, E.M. Elliott, S. Sather, and G.L. Johnson. 1996. Molecular cloning of mitogen-activated protein/ERK kinase kinases (MEKK) 2 and 3. J. Biol. Chem. 271: 53615368.

Cao, Z., W.J. Henzel, and X. Gao. 1996a. IRAK: A kinase associated with the interleukin-1 receptor. Science 271: 11281131.

Cao, Z., J. Xiong, M. Takeuchi, T. Kurama, and D.V. Goeddel. 1996b. TRAF6 is a signal transducer for interleukin-1. Nature 383: 443-446.

Cardone, M.H., G.S. Salvesen, C. Widmann, G. Johnson, and S.M. Frisch. 1997. The regulation of anoikis: MEKK-1 activation requires cleavage by caspases. Cell 90: 315-323.

Chen, C.C. and A.M. Manning. 1995. Transcriptional regulation of endothelial cell adhesion molecules: A dominant role for NF-кB. Agents Actions Suppl. 47: 135-141.

Cheng, G. and D. Baltimore. 1996. TANK, a co-inducer with TRAF2 of TNF- and CD 40L-mediated NF-кB activation. Genes \& Dev. 10: 963-973.

Cheng, G., A.M. Cleary, Z.-S. Ye, D.I. Hong, S. Lederman, and D. Baltimore. 1995. Involvement of CRAF1, a relative of TRAF, in CD40 signaling. Science 267: 1494-1498.

Chinnaiyan, A.M., K. O'Rourke, M. Tewari, and V.M. Dixit. 1995. FADD, a novel death domain-containing protein, interacts with the death domain of Fas and initiates apoptosis. Cell 81: 505-512.

Dendorfer, U., P. Oettgen, and T.A. Libermann. 1994. Multiple regulatory elements in the interleukin- 6 gene mediate induction by prostaglandins, cyclic AMP, and lipopolysaccharide. Mol. Cell. Biol. 14: 4443-4454.

Dérijard, B., M. Hibi, I.-H. Wu, T. Barrett, B. Su, T. Deng, M. Karin, and R.J. Davis. 1994. JNK1: A protein kinase stimulated by UV light and Ha-Ras that binds and phosphorylates the c-Jun activation domain. Cell 76: 1025-1037.

Dérijard, B., J. Raingeaud, T. Barrett, I.H. Wu, J. Han, R.J. Ulevitch, and R.J. Davis. 1995. Independent human MAP-kinase signal transduction pathways defined by MEK and MKK isoforms. Science 267: 682-685. 
DiDonato, J.A., M. Hayakawa, D.M. Rothwarf, E. Zandi, and M. Karin. 1997. A cytokine-responsive IкB kinase that activates the transcription factor NF-кB. Nature 388: 548-554.

Dinarello, C.A. 1994. The interleukin-1 family: 10 years of discovery. FASEB T. 8: 1314-1325.

Duckett, C.S., R.W. Gedrich, M.C. Gilfillan, and C.B. Thompson. 1997. Induction of nuclear factor $\kappa \mathrm{B}$ by the CD30 receptor is mediated by TRAF1 and TRAF2. Mol. Cell. Biol. 17: 1535-1542.

Farina, A.R., L. Cappabianca, A.R. Mackay, A. Tiberio, A. Tacconelli, A. Tessitore, L. Frati, S. Martinotti, and A. Gulino. 1997. Transcriptional regulation of intercellular adhesion molecule 1 by phorbol ester in human neuroblastoma cell line SK-N-SH involves jun- and fos-containing activator protein 1 site binding complex(es). Cell Growth Differ. 8: 789800

Faux, M.C. and J.D. Scott. 1996. Molecular glue: Kinase anchoring and scaffold proteins. Cell 85: 9-12.

Greenfeder, S.A., P. Nunes, L. Kwee, M. Labow, R.A. Chizzonite, and G. Ju. 1995. Molecular cloning and characterization of a second subunit of the interleukin 1 receptor complex. $J$. Biol. Chem. 270: 13757-13765.

Han, J., J.D. Lee, L. Bibbs, and R.J. Ulevitch. 1994. A MAP kinase targeted by endotoxin and hyperosmolarity in mammalian cells. Science 265: 808-811.

Heldin, C.H. 1995. Dimerization of cell surface receptors in signal transduction. Cell 80: 213-223.

Hsu, H., J. Xiong, and D.V. Goeddel. 1995. The TNF receptor 1 -associated protein TRADD signals cell death and NF-кB activation. Cell 81: 495-504.

Hsu, H., H.B. Shu, M.G. Pan, and D.V. Goeddel. 1996. TRADDTRAF2 and TRADD-FADD interactions define two distinct TNF receptor 1 signal transduction pathways. Cell 84: 299308.

Ichijo, H., E. Nishida, K. Irie, P. ten Dijke, M. Saitoh, T. Moriguchi, M. Takagi, K. Matsumoto, K. Miyazono, and Y. Gotoh. 1997. Induction of apoptosis by ASK1, a mammalian MAPKKK that activates SAPK/JNK and p38 signaling pathways. Science 275: 90-94.

Ihle, J.N. 1996. Janus kinases in cytokine signaling. Philos. Trans. R. Soc. Lond. B Biol. Sci. 351: 159-166.

Kallunki, T., B. Su, I. Tsigelny, H.K. Sluss, B. Dérijard, G. Moore, R. Davis, and M. Karin. 1994. JNK2 contains a specificity-determining region responsible for efficient c-Jun binding and phosphorylation. Genes \& Dev. 8: 2996-3007.

Karin, M. 1995. The regulation of AP-1 activity by mitogenactivated protein kinases. J. Biol. Chem. 270: 16483-16486.

Karin, M. and M. Delhase. 1998. JNK or IKK, AP-1 or NF-кB, which are the targets for MEK kinase 1 action? Proc. Natl. Acad. Sci. 95: 9067-9069.

Katz, P., G. Whalen, and J.H. Kherl. 1994. Differential expression of a novel protein kinase in human B lymphocytes. $J$. Biol. Chem. 269: 16802-16809.

Kyriakis, J.M., P. Banerjee, E. Nikolakaki, T. Dai, E.A. Rubie, M.F. Ahmad, J. Avruch, and J.R. Woodgett. 1994. The stressactivated protein kinase subfamily of c-Jun kinases. Nature 369: 156-160.

Lange-Carter, C.A., C.M. Pleiman, A.M. Gardner, K.J. Blumer, and G.L. Johnson. 1993. A divergence in the MAP kinase regulatory network defined by MEK kinase and Raf. Science 260: 315-319.

Lee, F.S., J. Hagler, Z.J. Chen, and T. Maniatis. 1997. Activation of the IкB $\alpha$ kinase complex by MEKK1, a kinase of the JNK pathway. Cell 88: 213-222.

Lee, F.S., R.T. Peters, L.C. Dang, and T. Maniatis. 1998. MEKK1 activates both IкB kinase $\alpha$ and IкB kinase $\beta$. Proc. Natl.
Acad. Sci. 95: 9319-9324.

Lee, J.C., J.T. Laydon, P.C. McDonnell, T.F. Gallagher, S. Kumar, D. Green, D. McNulty, M.J. Blumenthal, J.R. Heys, S.W. Landvatter, J.E. Strickler, M.M. McLaughlin, I.R. Siemens, S.M. Fisher, G.P. Livi, J.R. White, J.L. Adams, and P.R. Young. 1994. A protein kinase involved in the regulation of inflammatory cytokine biosynthesis. Nature 372: 739-746.

Lee, S.Y., A. Reichlin, A. Santana, K.A. Sokol, M.C. Nussenzweig, and Y. Choi. 1997. TRAF2 is essential for JNK but not NF- $\mathrm{BB}$ activation and regulates lymphocyte proliferation and survival. Immunity 7: 703-713.

Lin, A., A. Minden, H. Martinetto, F.X. Claret, C. Lange-Carter, F. Mercurio, G.L. Johnson, and M. Karin. 1995. Identification of a dual specificity kinase that activates the Jun kinases and p38-Mpk2. Science 268: 286-290.

Liu, Z.-G., H. Hu, D.V. Goeddel, and M. Karin. 1996. Dissection of TNF receptor 1 effector functions: JNK activation is not linked to apoptosis, while NF- $\mathrm{kB}$ activation prevents cell death. Cell 87: 565-576.

Malinin, N.L., M.P. Boldin, A.V. Kovalenko, and D. Wallach. 1997. MAP3K-related kinase involved in NF-кB induction by TNF, CD95 and IL-1. Nature 385: 540-544.

Maniatis, T., E.F. Fritsch, and J. Sambrook. 1989. Molecular cloning: A laboratory manual. Cold Spring Harbor Laboratory Press, Cold Spring Harbor, NY.

Martin, T., P.M. Cardarelli, G.C. Parry, K.A. Felts, and R.R. Cobb. 1997. Cytokine induction of monocyte chemoattractant protein-1 gene expression in human endothelial cells depends on the cooperative action of NF-кB and AP-1. Eur. J. Immunol. 27: 1091-1097.

Mercurio, F., H. Zhu, B.W. Murray, A. Shevchenko, B.L. Bennett, J. Li, D.B. Young, M. Barbosa, M. Mann, A. Manning, and A. Rao. 1997. IKK-1 and IKK-2: Cytokine-activated IкB kinases essential for NF-кB activation. Science 278: 860-866.

Minden, A., A. Lin, M. McMahon, C. Lange-Carter, B. Dérijard, R.J. Davis, G.L. Johnson, and M. Karin. 1994. Differential activation of ERK and JNK mitogen-activated protein kinases by Raf-1 and MEKK. Science 266: 1719-1723.

Minden, A., A. Lin, F.X. Claret, A. Abo, and M. Karin. 1995. Selective activation of the JNK signaling cascade and c-Jun transcriptional activity by the small GTPases Rac and Cdc42Hs. Cell 81: 1147-1157.

Nakano, H., H. Oshima, W. Chung, L. Williams-Abbott, C.F. Ware, H. Yagita, and K. Okumura. 1996. TRAF5, an activator of NF- $\mathrm{kB}$ and putative signal transducer for the lymphotoxin- $\beta$ receptor. J. Biol. Chem. 271: 14661-14664.

Natoli, G., A. Costanzo, A. Ianni, D.J. Templeton, J.R. Woodgett, C. Balsano, and M. Levrero. 1997. Activation of SAPK/JNK by TNF receptor 1 through a noncytotoxic TRAF2-dependent pathway. Science 275: 200-203.

Régnier, C.H., H.Y. Song, X. Gao, D.V. Goeddel, Z. Cao, and M. Rothe. 1997. Identification and characterization of an IкB kinase. Cell 90: 373-383.

Reinhard, C., B. Shamoon, V. Shyamala, and L.T. Williams. 1997. Tumor necrosis factor $\alpha$-induced activation of c-Jun $\mathrm{N}$-terminal kinase is mediated by TRAF2. EMBO $J$. 16: $1080-1092$.

Roger, T., T. Out, N. Mukaida, K. Matsushima, H. Jansen, and R. Lutter. 1998. Enhanced AP-1 and NF-кB activities and stability of interleukin 8 (IL-8) transcripts are implicated in IL-8 mRNA superinduction in lung epithelial H292 cells. Biochem. J. 330: 429-435.

Rothe, M., S.C. Wong, W.J. Henzel, and D.V. Goeddel. 1994. A novel family of putative signal transducers associated with the cytoplasmic domain of the $75 \mathrm{kD}$ tumor necrosis factor 
receptor. Cell 78: 681-692.

Rothe, M., V. Sarma, V.M. Dixit, and D.V. Goeddel. 1995. TRAF-2-mediated activation of NF-кB by TNF receptor 2 and CD40. Science 269: 1424-1427.

Rothe, M., J. Xiong, H.B. Shu, K. Williamson, A. Goddard, and D.V. Goeddel. 1996. I-TRAF is a novel TRAF-interacting protein that regulates TRAF-mediated signal transduction. Proc. Nat1. Acad. Sci. 93: 8241-8246.

Rothwarf, D.M., E. Zandi, G. Natoli, and M. Karin. 1998. IKK- $\gamma$ is an essential regulatory subunit of the IкB kinase complex. Nature 395: 297-300.

Rouse, J., P. Cohen, S. Trigon, M. Morange, A. Alonso-Llamazares, D. Zamanillo, T. Hunt, and A.R. Nebreda. 1994. A novel kinase cascade triggered by stress and heat shock that stimulates MAPKAP kinase- 2 and phosphorylation of the small heat shock proteins. Cell 78: 1027-1037.

Schlessinger, J. and A. Ullrich. 1992. Growth factor signaling by receptor tyrosine kinases. Neuron 9: 383-391.

Schreiber, S.L. 1991. Chemistry and biology of the immunophilins and their immunosuppressive ligands. Science 251: 283 287.

Song, H.Y., C.H. Régnier, C.J. Kirschning, D.V. Goeddel, and M. Rothe. 1997. Tumor necrosis factor (TNF)-mediated kinase cascades: Bifurcation of nuclear factor $\mathrm{\kappa B}$ and c-jun N-terminal kinase (JNK/SAPK) pathways at TNF receptor-associated factor 2. Proc. Natl. Acad. Sci. 94: 9792-9796.

Spencer, D.M., T.J. Wandless, S.L. Schreiber, and G.R. Crabtree. 1993. Controlling signal transduction with synthetic ligands. Science 262: 1019-1024.

Stanger, B.Z., P. Leder, T.H. Lee, E. Kim, and B. Seed. 1995. RIP: A novel protein containing a death domain that interacts with Fas/APO-1 (CD95) in yeast and causes cell death. Cell 81: 513-523.

Takeuchi, M., M. Rothe, and D. V. Goeddel. 1996. Anatomy of TRAF2. Distinct domains for nuclear factor- $\mathrm{kB}$ activation and association with tumor necrosis factor signaling proteins. J. Biol. Chem. 16: 19935-19942.

Tartaglia, L.A. and D.V. Goeddel. 1992. Two TNF receptors. Immunol. Today 13: 151-153.

Tracey, K.J. and A. Cerami. 1993. Tumor necrosis factor, other cytokines and disease. Annu. Rev. Cell Biol. 9: 317-343.

Vanden Berghe, W., S. Plaisance, E. Boone, K. De Bosscher, M. L. Schmitz, W. Fiers, and G. Haegeman. 1998. p38 and extracellular signal-regulated kinase mitogen-activated protein kinase pathways are required for nuclear factor- $\mathrm{kB}$ p 65 transactivation mediated by tumor necrosis factor. J. Biol. Chem. 273: 3285-3290.

Verma, I.M., J.K. Stevenson, E.M. Schwarz, D. Van Antwerp, and S. Miyamoto. 1995. Rel/NF-кB/IкB family: Intimate tales of association and dissociation. Genes \& Dev. 9: 2723 2735.

Wesche, H., W.J. Henzel, W. Shillinglaw, S. Li, and Z. Cao. 1997. MyD88: An adapter that recruits IRAK to the IL-1 receptor complex. Immunity 7: 837-847.

Westwick, J.K., C. Weitzel, A. Minden, M. Karin, and D.A. Brenner. 1994. Tumor necrosis factor $\alpha$ stimulates AP-1 activity through prolonged activation of the c-Jun kinase. J. Biol. Chem. 269: 26396-26401.

Widmann, C., P. Gerwins, N.L. Johnson, M.B. Jarpe, and G.L. Johnson. 1998. MEK kinase 1, a substrate for DEVD-directed caspases, is involved in genotoxin-induced apoptosis. Mol. Cell. Biol. 18: 2416-2429.

Woronicz, J.D., X. Gao, Z. Cao, M. Rothe, and D.V. Goeddel. 1997. ІкB kinase- $\beta$; NF-кB activation and complex formation with ІкB kinase- $\alpha$ and NIK. Science 278: 866-869.

Xia, Y., Z. Wu, B. Su, B. Murray, and M. Karin. 1998. JNKK1 organizes a MAP kinase module through specific and sequential interactions with upstream and downstream components mediated by its amino-terminal extension. Genes \& Dev. 12: 3369-3381.

Yamaoka, S., G. Courtois, C. Bessia, S.T. Whiteside, R. Weil, F. Agou, H.E. Kirk, R.J. Kay, and A. Isräel. 1998. Complementation cloning of NEMO, a component of the ІкB kinase complex essential for NF-кB activation. Cell 93: 1231-1240.

Yeh, W.C., A. Shahinian, D. Speiser, J. Kraunus, F. Billia, A. Wakeham, J.L. de la Pompa, D. Ferrick, B. Hum, N. Iscove, P. Ohashi, M. Rothe, D.V. Goeddel, and T.W. Mak. 1997. Early lethality, functional NF-кB activation, and increased sensitivity to TNF-induced cell death in TRAF2-deficient mice. Immunity 7: 715-725.

Yin, M.J., L.B. Christerson, Y. Yamamoto, Y.T. Kwak, S. Xu, F. Mercurio, M. Barbosa, M.H. Cobb, and R.B. Gaynor. 1998. HTLV-1 Tax protein binds to MEKK1 to stimulate IкB kinase activity and NF-кB activation. Cell 93: 875-884.

Yuasa, T., S. Ohno, J.H. Kehrl, and J. M. Kyriakis. 1998. Tumor necrosis factor signaling to stress-activated protein kinase (SAPK)/Jun $\mathrm{NH}_{2}$-terminal kinase (JNK) and p38. J. Biol. Chem. 273: 22681-22692.

Zandi, E., D.M. Rothwarf, M. Delhase, M. Hayakawa, and M. Karin. 1997. The IкB kinase complex (IKK) contains two kinase subunits, IKK $\alpha$ and IKK $\beta$, necessary for IKB phosphorylation and NF-кB activation. Cell 91: 243-252.

Zandi, E., Y. Chen, and M. Karin. 1998. Direct phosphorylation of IKB by IKK $\alpha$ and IKK $\beta$ : Discrimination between free and NF-кB-bound substrate. Science 281: 1360-1363. 


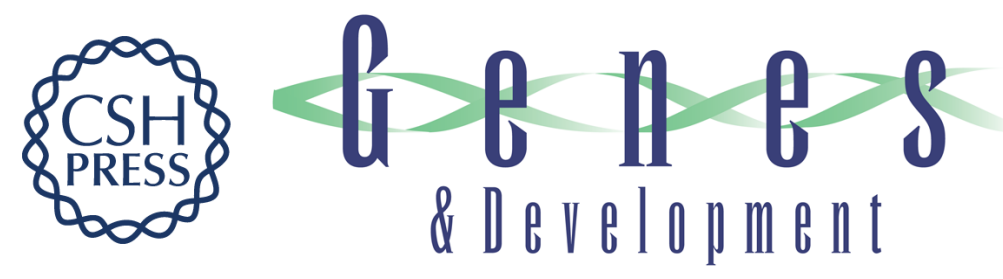

\section{Signaling by proinflammatory cytokines: oligomerization of TRAF2 and TRAF6 is sufficient for JNK and IKK activation and target gene induction via an amino-terminal effector domain}

Véronique Baud, Zheng-Gang Liu, Brydon Bennett, et al.

Genes Dev. 1999, 13:

References

This article cites 73 articles, 38 of which can be accessed free at:

http://genesdev.cshlp.org/content/13/10/1297.full.html\#ref-list-1

License

Email Alerting

Service

Receive free email alerts when new articles cite this article - sign up in the box at the top right corner of the article or click here.

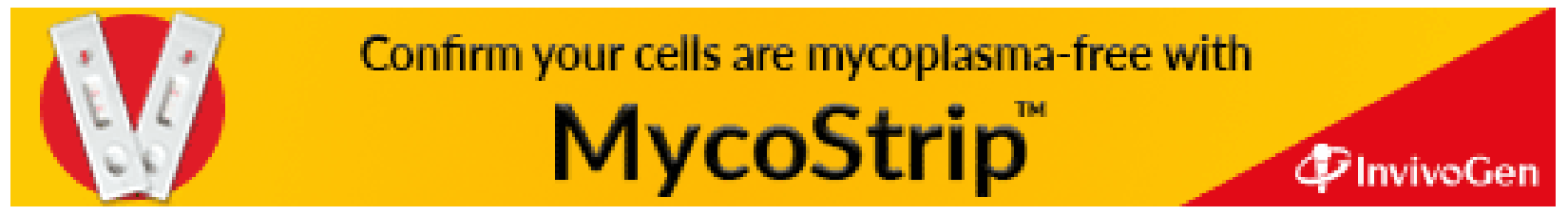

